Gábor Pusztai

\title{
Wisselend toeschouwer en participant
}

\author{
Interview met Siel van der Ree
}

U hebt een Hongaarse voornaam, Szilárd. Hoe komt dat? Kunt u iets over uw familieachtergrond vertellen?

Szilárd Constantin, mijn voornamen, betekenen nogal wat: krachtfiguur en aanhouder. Szilárd heb ik maar veranderd in de roepnaam Siel, een beetje Deens- en Friesachtig. Het waren de voornamen van mijn Hongaarse grootvader, aan het eind van de eerste wereldoorlog gestorven: een gifgasaanval aan het front, vervolgens naar huis, daar zeven maanden gehoest en toen dood. Zijn vrouw, mijn 'Oma Dallos' (Zsuzsanna Kupás, Diószeg 4 oktober 1889 - Den Haag, 21 december 1978) had geen perspectief meer in Hongarije, werd eerst begeleider in de kindertreinen naar Nederland, nam een keer haar dochter mee, parkeerde die bij streng gereformeerde pleegouders en vestigde zich later metterwoon in Nederland. Ik hoor het haar nog zeggen: Jeetje toe, Jasje an! Het was haar verbastering van Jeetje en Jasses nog aan toe, opgepikt in de keukens waar ze jarenlang als kokkin gewerkt had. Tussen haar en het gastland kwam het communicatief nooit goed. De taal die ze in de keukenpraktijk opgepikt had was ongeschikt voor het overbruggen van de cultuurkloof tussen beide landen. Weliswaar had vooral Oost-Hongarije, mede dankzij Michiel de Ruyter, ${ }^{1}$ eeuwenlang religieuze contacten met Calvinistisch Nederland; maar de gewone Hongaar heeft zo'n volstrekt andere kijk op het leven, dat overbrug je niet met wat culinair Nederlands. Bijgevolg heeft mijn oma haar leven lang in onzekerheid geleefd over bedoelingen en vooral bijbedoelingen van de mensen met wie ze praatte. ${ }^{2}$ Het leek 
soms alsof ze doof was, zo onzeker kon ze reageren op in mijn ogen onschuldig bedoelde opmerkingen. De laatste jaren van haar leven reageerde ze op àlles met achterdocht: zocht erachter wat er niet was. De eeuwige buitenstaander. De laatste weken voor haar dood heeft ze huilend doorgebracht, afsluiting van een in feite ellendig bestaan. Het woord ellende gaat terug op banneling zijn: elders, in een ander land moeten leven, waar je geen bescherming hebt van familie en vrienden, erger kan niet. Mijn oma heeft mij geleerd wat ellende betekent. Helaas realiseerde ik me dat pas toen ik, dertig jaar na haar dood, met vluchtelingen ging werken.

\section{$U$ heeft dus een persoonlijke band met de Hongaarse kindertreinen.}

Alleen indirect, via mijn moeder, Irene (Irene Isabella Dallos, Boedapest, 11 januari 1912 - Den Haag, 15 april 2008). Zij werd als 8-jarige vanuit Boedapest helemaal alleen gedropt in een vreemd land, want haar moeder ging aan het werk als kokkin in keukens van de Haute Chique. Zij was dus totaal op zichzelf teruggeworpen, tussen mensen die niets van kinderen begrepen. Ze begon dan ook met zwijgen, zólang dat er een Hongaars sprekende logopediste bij werd gehaald. 'Waarom praat je niet?' vroeg die. 'Omdat ik niets te zeggen heb', antwoordde Ireentje, 'Ik praat wel als ik iets te zeggen heb.' Deze houding, behorend bij de perfectionist die ze was, heeft ze haar leven lang volgehouden. Zij heeft zich uiterst slim aangepast aan haar gastland, leerde echt 'keurige' manieren en ging naar de MULO waar ze Dien van der Ree ontmoette, een 'dikke vriendin', die overigens vond dat Irene's Nederlandse (her)opvoeding neerkwam op kindermishandeling èn die haar later liet kennismaken met haar oudere broer Ad. Deze was op verlof uit 'De Oost' (=Nederlands-Indië). Daar was hij heen gegaan omdat er ten tijde van de economische crisis van de dertiger jaren voor een ingenieur geen werk te vinden was in Nederland. Vóór de oorlog in Atjeh, daarna op Zuid-Sumatra werkte hij voor de 'Stanvac' (de productieafdeling van Esso, die daar naar olie boorde). Naar dat Nederlands-Indië ging Irene mee, na haar huwelijk met hem. Met Ad heeft ze er een goed leven gehad, een luxe koloniaal bestaan. Tot de oorlog kwam en daarna de internering op Java, waar ze haar gevecht leverde om met drie kinderen het 'Jappenkamp' te overleven.

Wat maakte die overleving dan tot een gevecht? 
Japanners hebben een voor Europeanen moeilijk te begrijpen cultuur, met naast een extreme beleefdheid een enorm arbeidsethos en een keiharde discipline, ook en vooral in het leger, waarbij vreselijk geslagen kan worden. Ook nu zijn lijfstraffen nog schering en inslag, niet alleen in de sport (waar b.v. een volleyballer 13 keer vlak in het gezicht geslagen werd terwijl het team toekeek en gelukkig eentje het filmde), maar ook bij de opvoeding van kleine kinderen (waarbij zelfs het risico van doodslag genomen wordt), zoals Human Rights Watch nog recentelijk berichtte. Vertaal deze 'barbaarse' mores naar een interneringskamp vol vrouwen en kinderen, steeds verder verzwakte mensen, die ooit gewend waren op hun wenken bediend te worden en nu, als ze niet bogen als knipmessen voor èlke passerende Japanse soldaat, in elkaar geslagen konden worden. En denk even aan de uithongering ${ }^{3}$ en vernedering van deze 'blanke kolonialen en onderdrukkers van Azië', en je krijgt een beeld van een tragische geschiedenis van vernedering, vervuiling en ontreddering, dat ook ronduit walgelijk is. Tel daarbij op de verkrachting van z.g. 'troostmeisjes' (meisjes en jonge vrouwen voor hun bordelen) en je voelt iets van die ellende. De vrouwen, die hun kinderen heelhuids door deze periode heen loodsten, hebben daar soms bovenmenselijk veel voor over gehad en waren in mijn ogen de èchte oorlogsheldinnen.

\section{Hoe is het met uw ouders afgelopen?}

$\mathrm{Na}$ de oorlog terug in Nederland konden mijn ouders, totaal berooid, opnieuw beginnen. Ze zijn, na een verlof, teruggegaan naar Indonesië, eerst met de drie kinderen van voor de oorlog (en daarna met nog twee erbij van na de oorlog). Die periode, op Zuid-Sumatra, is de leukste tijd van mijn jeugd geworden. Vanaf eind 1952 was het gezin weer herenigd, nu in Den Haag, waar Esso haar Nederlandse hoofdkantoor had. Daar hebben ze het samen goed gehad, tot het overlijden van mijn vader. Na de dood van haar Ad ging mijn moeder op haar zeventigste weer studeren, kunstgeschiedenis en Hongaars, haar moedertaal die ze naar eigen zeggen vergeten was. Toen zij 80 werd is ze met de hele familie met vijf auto's en één motorfiets naar Boedapest gereisd, waar zij volop kon genieten van de dingen die ze herkende, haar woordje weer kon doen èn zelfs keurig converseren met de Hongaarse gentleman, die haar tijdens haar verjaardagsfeest on-Nederlands galant ten dans vroeg. 
Hoe waren uw jeugdjaren?

Mijn jeugdjaren waren turbulent, maar dat hoorde gewoon bij die tijd. Geboren in Nederlands-Indië belandde ik op mijn vierde jaar in het Japanse interneringskamp, op mijn negende in Thailand, toen nog Siam (om mijn vader terug te vinden ${ }^{4}$, die als krijgsgevangene gewerkt had aan de Birmalijn), daarna bijna een jaar in Nederland, toen weer drie jaar op Sumatra en op mijn dertiende weer in Nederland, waar ik heen moest omdat het onderwijs er zo goed was (geloven velen nog steeds) en werd opgevangen in ... een streng gereformeerd gezin (waarover overigens niets dan goeds!), mijn eerste culture shock: de kennismaking met lasten en plichten van het ware geloof viel niet mee. Dat was in 1950, een tijd dat er niet minder discriminatie was dan nu. Ik sprak 'Klipsteen', Nederlands met een 'Indisch accent', en signaleerde bij zowat iedereen een lichte, kennelijk niet te onderdrukken frons als ik wat zei. Dus heb ik mij toegelegd op het leren spreken van bekakt NL en toen werd ik wèl geloofd. Ik had ervaren dat kleine afwijkingen van de vorm de inhoud van taaluitingen volkomen kan overschaduwen: men houdt eenvoudig op met serieus luisteren. En het toenmalige vooroordeel tegen halfbloeds en Indo's neutraliseerde ik door uit te leggen, dat ik weliswaar een halfbloed was, maar met Europese roots. Dan telde je wèl mee en was je niet een Indo en 'natuurlijk achterbaks.' 5 Jaren later realiseerde ik me, dat je als gediscrimineerde dus zelf kunt gaan meedoen aan het versterken van de vooroordelen. Mijn middelbare schooljaren verliepen wat jammerlijk, waarschijnlijk het gevolg van het feit dat ik aanvankelijk wèl de betekenis van alle uitingen kende, maar niet hun referentie of achtergrond. ${ }^{6}$ Ik hoorde er niet echt bij, hoorde dingen aan die ik niet goed kon plaatsen of zelfs haatte en voelde me een importje, dat niet verder kwam dan toeschouwer blijven.

\section{Waarom ging u Nederlands studeren? En waarom juist in Leiden?}

Ik had eigenlijk geoloog willen worden, een wetenschappelijk bestaan in de rimboe, waar ik zoveel gespeeld had en verboden dingen gedaan. Maar met mijn exacte vakken wilde het niet vlotten, dus moest het iets anders worden. Nederlands heb ik gekozen dankzij de heer Hissink, een lichtend voorbeeld van een tolerant en beminnelijk mens, die echt meeslepend kon vertellen: een model leraar, die de meest onverschillige pubers kon inspireren maar ook gewoon mee ging schaatsen. De academische studie Nederlands zelf vond ik van een enorme kwantiteit (rustig 150 boeken voor 
één tentamen) en zeer matige kwaliteit, behoudens één vak: structuralistische taalkunde. Ik ben pas echt opgeleefd toen ik me tijdens de doctoraalfase kon verdiepen in Algemene Taalwetenschap. Dat ik docent wilde worden hangt waarschijnlijk ook samen met mijn rol bij ons thuis: de oudste in een gezin met vijf kinderen. Een steekproef in de tachtiger jaren onder vier lichtingen (telkens 120) eerstejaars aan de NLO wees uit, dat het aantal oudsten en jongsten, die kiezen voor het onderwijs, relatief groot is. Waarom Leiden? Dat was dichtbij en voor mij als werkstudent (toen feitelijk een zwaar bestaan) dus best handig. Het was voor mijn latere carrière ook wel aardig wegens de vergader-, kakgedrag- en grote bek-technieken die je er opdoet.

In 1956 kwamen Hongaarse vluchtelingen naar Nederland. Kunt u zich die jaren, de sfeer, en de mensen herinneren?

De sfeer, die ik me kan herinneren, was die van machteloze woede en frustratie, onvergetelijk. Er waren beelden van het geweld in Boedapest, maar niemand kwam te hulp. Dat was buitengewoon verdrietig en beschamend, niet alleen voor iemand met een kampgeschiedenis en ooit bevrijd door het Engelse leger. Ik herinner me dat ook veel klasgenoten verbijsterd en beschaamd waren dat er niks gebeurde. Met de vluchtelingen die hier later kwamen was grote solidariteit. Maar natuurlijk moest de politiek (Kabinet Den Uyl) weer e.e.a. verpesten, zoals de weigering meer dan 40 kinderen (van 1300 noodgevallen!) op te vangen en dat alleen na keuring door een Hollandse 'zieltjesknijper'. Maar bij mijn weten zijn de volwassen (3300) vluchtelingen redelijk goed opgevangen en hebben ze zich slim aangepast en carrière kunnen maken. 'Ze konden goed leren', was de mare. Ik neem aan, dat die vluchtelingen zich net zo aangepast hebben als ik: altijd toeschouwer, soms ook participant. Door een toeval speelde ene Palkó Lakatos, zoon van zo'n vluchteling, een grappige rol in mijn carrière. Maar daarvoor moet je bij 'frustraties' zijn. Via mijn oma heb ik, weer jaren later, nog contact met wat vluchtelingen gehad, van wie er eentje diepe indruk op mij gemaakt heeft door de wijze waarop hij uitlegde dat er in Europa een diepe kloof bestaat tussen Oost en West: het Oosten, rond Polen en Hongarije, had veel minder of hoegenaamd niet te maken gehad met Renaissance en Verlichting, zo zei hij het, en zich dientengevolge anders ontwikkeld, met een heel andere rol voor emoties, tradities en kerk. 'Het presidentschap, dat is mijn lot', zegt de één. 'Het is mijn roeping', zegt de ander. Volgens hem onoverbrugbaar, die kloof. 
Gezien de recente geschiedenis van de Europese Unie geef ik hem nu, zo'n 60 jaar later, gelijk; al ben ik niet zo zeker van zijn verklaring.

Kunt u uw onderwijscarrière beschrijven, bijvoorbeeld in fasen, leermomenten, ontdekkingen of desnoods frustraties?

Die carrière is gestart als werkstudent: daarbij heb ik een paar leerlingen met zg. onoverkomelijke moeilijkheden door een leerjaar of aan een diploma geholpen. Meest markante ervaring: een (door als kleuter opgelopen 'Niet Aangeboren Hersenletsel') zwaar gehandicapte jongen, die echt dacht niets te kunnen en die ik pas gemotiveerd aan het werk kreeg nadat hij ontdekt had, dat hij wel degelijk iets bijzonders kon presteren: ook al ben je helemaal scheefgegroeid toch leren rijden op mijn zware motor. Uiterst leerzaam is geweest de periode, waarin ik als zeilinstructeur, in zeilkampen van middelbare scholieren, een aantal jaren telkens zo'n 50 leerlingen meemaakte in hun gewone doen, dus het hele scala van enerzijds hulpvaardig en sociaalvoelend, handig en overal inzetbaar (vaak uit grote gezinnen) en anderzijds puberaal en dwars, zich drukkend en vol ongein die ze zelf erg leuk vonden. Maar zo'n 'ettertje' kon vier jaar later terugkeren als instructeur met een behoorlijk ontwikkeld verantwoordelijkheidsgevoel! Daar zag ik ook de grote gevolgen, die een kleine vergissing in de instructie kan veroorzaken: ernstige verwondingen, aanvaringen met bijna fatale gevolgen. Ook een ervaring, zij het niet zo positief, was de cursus Russisch die ik in militaire dienst volgde met wat the American Army Method werd genoemd, een leer-of-ik-schiet aanpak, mèt een talenlab en Russische native speakers, die verscheidene mede-dienstplichtigen letterlijk gek maakte: het tempo was hoog, je werd geacht in zes maanden vertaler en nog eens zes tolk (ook náár de vreemde taal!) te zijn. De eerste weken vielen er dan ook de nodigen af, totaal overspannen. Ik had het geluk voldoende te weten van etymologie om allerlei moeilijke woorden terug te kunnen voeren op Nederlandse equivalenten, bijvoorbeeld robota op arbeid of bjéreg (oever, dus verhoging naast een nat oppervlak) op berg (verhoging, overal). Het heeft me echt geholpen door een berg leerstof, die kennelijk ziekmakend kon zijn. Gelukkig was er ook muziek, in het kader van Ruslandkunde: vaak beeldschone melodieën van in hoofdzaak volksliedjes, die niet alleen iets zeiden over de 'Russische volksziel' maar me ook geleerd hebben dat dat zowat het enige is, dat je na tientallen jaren nog kunt reproduceren. Het belang van muziek voor grammatica en opslag in het geheugen heb ik daaraan overgehouden. 
Mijn eerste officiële baantje was op de Middelbare Handelsdagschool, waarop leerlingen zaten, naar eigen zeggen vooral om fiscale redenen, en waar ik kennismaakte met een ruig type leerders, die alleen aan het werk wilden voor zinvolle taken òf na ernstige chantage. Ik had daar een geweldig prestige omdat ik naar school kwam in een antieke Mercedes, het laatste Hitlermodel (1951). En dat gaf me een duidelijke voorsprong, waardoor mijn leerlingen kennelijk bereid waren meer te doen dan voor collega's. Als ze wat presteerden was dat vaak indrukwekkend: spreekbeurten met echte demo's, bijvoorbeeld met karts (mini racewagens), hele school blauw van de uitlaatgassen! Of met postduiven, die werden besproken èn gelost, met een toto erbij ('wie gokt welke er het eerst weer thuis is?'), hele administratie, ingeschakeld voor de toto, op stelten. Ik heb ervan overgehouden dat leerlingen tot zinvolle spreekbeurten of verantwoorde schrijfprestaties komen als ze in eigen ogen iets relevants te vertellen hebben aan een te overtuigen publiek.

\section{En, die frustraties? Kunt u daar wat van vertellen?}

Markant is gebleven de ervaring met een Hongaarse leerling op die school, Palkó Lakatos: tijdens de borrel voor de geslaagde eindexamenkandidaten kwam hij met nog wat leerlingen op me af. 'Meneer, we moeten u spreken. Niet hier, even op de gang. (...) U moet eruit, uit het onderwijs, u moet niet blijven. U hoort er niet bij.'

Ik: 'Hoezo, Palkó? We hebben toch lol gehad, jullie hebben hard gewerkt en zondermeer schitterende resultaten behaald, zelfs voor die ellendige opstellen.'

Palkó: 'Ja meneer, maar dat is het niet.'

Ik: 'Er was notabene geen enkele leerling met een onvoldoende voor Nederlands!'

Palkó: 'Ja, het was goed, echt. Maar u moet ermee ophouden, iets anders gaan doen. U hoort niet thuis in het onderwijs. Ze maken u kapot.'

Ik: 'Hè, hoezo?'

Palkó: 'Tja, ... nou, het klopt gewoon niet, u kan zich op school wel thuis voelen, maar u hoort er niet. $U$ moet eruit, anders zullen ze wel u klein krijgen.'

Zijn advies heb ik niet opgevolgd, maar er wel vaak aan terug gedacht. Frustraties? Wie werkt er zonder in het onderwijs? Als mentor op mijn volgende school, een kak-HAVO \& VWO in de Randstad, kreeg ik ook te stellen met de psych(osomat)ische gevolgen voor sommige leerlingen van 
'vechtscheidingen': soms zondermeer gruwelijk, tot een verder leven in een rolstoel toe. En verder maakten het Ministerie, de Inspectie, Uitgeverijen en de nodige collega's het je niet makkelijk of werkten zelfs tegen, soms in de vorm van evidente rotstreken. Het Ministerie: afspraken niet nakomen en bij beslissingen het geld laten prevaleren boven de mens, daarbij rustig de auteursrechten van meeschrijvende collega's schendend en hen (op de Nederlandse Antillen) in feite tot nonvaleur verklarend èn hun werk tot rommel reducerend. De Inspectie: kinderen niet in hun moedertaal testen en dus ver beneden hun capaciteiten 'evalueren', goedbedoeld ja-zeggen en dan nee-doen. Uitgevers: vooral gericht op eigen kontzak en bereid daarvoor afspraken, ja zelfs contracten te schenden en concurrente methodieken op te kopen en om zeep te helpen. Collega's, ook aan universiteiten: zich laten verleiden je concurrent te worden en daarna in mijn ogen immoreel te handelen, in elk geval ten nadele van hun pupillen. Tezamen doen ze heel wat schade aan het onderwijs, niet te ontkennen. Maar ondanks Palkó's uitspraak heb ik zelden spijt gehad van mijn keuzen, want de studenten en later collega's (voor wie je het deed) reageerden over het algemeen positief. Of ze me klein gekregen hebben is een andere kwestie. Nòg een frustratie? In 1976 verscheen Hoe wij denken, leren en vergeten, ${ }^{7}$ een indringende publicatie over de fysieke werking van ons brein en consequenties voor ons geheugen, de psychische effecten in het traditionele onderwijs en wezenlijk nieuwe inzichten voor pedagogiek en didactiek. Het boek, berustend op zo'n 70 jaar hersenonderzoek, was een eyeopener, want het bevatte ook duidelijke aanwijzingen voor je gedrag in de klas. Wat mij verbijsterd heeft, met name tijdens nascholingscursussen die ik later gaf, was dat het onderwijs zich heel lang niets aangetrokken heeft van deze inzichten. Ik heb dan ook, bij gebrek aan beter, jarenlang maar zelf een website in de lucht gehad: Hersenwerk. Pas dankzij een figuur als Jolles ${ }^{8}$ kwam er zo'n veertig jaar na Vester's werk wat schot in het bewustmaken van de rol van een gezond en natuurlijk benaderd brein in het onderwijs.

In hoeverre heeft $u$ zelf voor uw werk profijt gehad van modern hersenonderzoek?

Doordat ik ook te maken kreeg met cursisten, veelal iets oudere vrouwen in de 'Basis Educatie', die geloofden (of liever: die vaak aangepraat was) dat ze niets konden, dus ook niet leren, moest ik mij nader oriënteren over hoe leren, liefst natuurlijk, kon verlopen: onderzoek van het brein en ge- 
heugenstrategieën. Ik heb erg veel gehad aan het werk van Vester, Jolles en Eveline Crone. ${ }^{9}$ Daaruit heb ik met name geleerd, op welke uiteenlopende manieren mensen dingen verwerven, oppikken of leren èn wat voor revolutie dat eigenlijk voor het onderwijs zou betekenen, àls dat er zich iets van aan zou trekken. Ik heb zelf onze methodiek, zowel voor alfabetisatie als voor NT2 \& VTO, op onderdelen kunnen aanpassen aan enige nieuwe inzichten, gedeeltelijk zelfs daterend uit ... 1907!

Wat verwacht $u$ van de dankzij het coronavirus versnelde ontwikkeling van ICT in het taalonderwijs?

Hersenonderzoek werd rond 2010 een soort hype, nog steeds vanuit de gedachte dat als je wist wáár in het brein activiteiten te signaleren waren, je ook wist hóe je dat soort activiteiten kon oproepen, resp. bijsturen. Het puberale en adolescente brein kregen veel aandacht, met mijns inziens nogal aftandse adviezen, althans voor wie op de hoogte was van de 'ouderwetse' ontwikkelingspsychologie. Ook ICT groeide vanaf de jaren negentig enorm, met soms aardige mogelijkheden voor het onderwijs. Zo hebben wij zelf een CD kunnen maken waarop taaloefeningen (uit Spreken is Zilver...) werkelijk interactief werden, beslist leuker en waarschijnlijk effectiever. Het voordeel was dat je de docentenrol aardig kon laten overnemen d.m.v. zó op te roepen feedback: verwijzingen naar de goede voorbeelden en naar grammaticaregels. Maar de basis bleef natuurlijk de audiolexicale methodiek, die uit het boekje kwam. Het enige wezenlijke verschil was de feedback en ... de besparing aan docentenuren! Wat ik (bij een poging nog wat Hongaars op te pikken) op internet getest heb viel me niet mee, vooral doordat men bestaande werkvormen en oefeningen gewoon overnam en niet aanvulde met nieuwe mogelijkheden. Het kwam eigenlijk neer op herhaling, herhaling, herhaling, en dat werkt niet echt. Een hybride (door internet aangevulde traditionele) leergang als MagyarOK (Szita Szilvia - Pelcz Katalin) vind ik wel veelbelovend. Ik heb verder over het gebruik van ICT in de coronatijd, van zowel leerlingen als andere thuiswerkers vernomen, dat bijv. werken met Skype, ZOOM of via FaceTime wel èrg veel extra tijd kostte en dat de meeste informanten hangend aan hun een scherm normale interactie zó misten, dat ze met een zucht van opluchting weer aan het gewone werk, resp. naar school gingen. Daar staat tegenover dat uit het bedrijfsleven wel heel optimistische geluiden komen. 
U was ook een tijdje in Indonesië. Wat deed u daar? Wat waren uw ervaringen?

Mijn lectoraat Nederlandse Taalbeheersing en Taalkunde in Indonesië is een verhaal apart. Ten eerste het bronnentaalprobleem, waaruit een 'Seksi Belanda' voortkwam: er was in Indonesië nog ontzettend veel wetgeving en andere relevante wetenschappelijke info, in de koloniale periode tot stand gekomen, die nog in het Nederlands stond en die voor de meeste vakgebieden onmisbaar was. En er waren in die periode (begin zeventiger jaren) nog duizenden fitte intellectuelen in dat land, die vanuit hun vakkennis èn hun onwaarschijnlijk goede beheersing van het Nederlands de belangrijkste vakliteratuur konden vertalen in het Indonesisch. Maar die deskundigen werden niet ingeschakeld, integendeel, de politiek koos voor een m.i. onrealistische oplossing van het probleem: de ooit bestaande Sectie Nederlands werd heropgericht en met hulp van Nederlandse lectoren aan het werk gezet om curricula te ontwikkelen, beschrijven \& testen voor Nederlands als hoofdvakstudie ${ }^{10}$ èn als bijvak voor al die studenten, die afhankelijk waren van Nederlandstalige bronnen en die de vreemde taal alleen moesten leren lezen, dus receptief beheersen. De sectie kreeg ook een zg. pembina-functie: het overdragen van succesvolle aanpakken aan andere staatsuniversiteiten, en wel d.m.v. nascholen en studiemateriaal beschikbaar stellen, een taak die heel wat tempo, tact en kerosine kostte, want je moest juridisch en bijv. landbouwkundig geschoolde collega's in korte tijd bijscholen, zo nodig helpen bij het opzetten van bijvakstudies (Nederlandse teksten leren lezen), andere projecten opzetten (en daarbij soms onderlinge fricties helpen oplossen) èn je vloog heel wat af, in Nederlandse Fokker Fellowships.

Bij de hoofdvakstudie geconfronteerd met studenten uit een totaal andere leefwereld, die hoegenaamd niets gelezen hadden, qua studievaardigheid het veel meer van het beeld en het gespróken woord dan van teksten moesten hebben (ze zouden nu massaal YouTube raadplegen) en die aangesproken wilden worden in hùn denkcategorieën, heb ik gedwongen afstand leren nemen van traditionele termen en begrippen in de taalkunde. Er bestond namelijk een soort koloniale grammatica, die de Bahasa Indonesia probeerde te beschrijven in vertrouwde categorieën, ook als die niet bestonden, zoals 'werkwoord' (als kern van een onderwerp-gezegde-object-bepalingen construct). Het Indonesisch heeft geen werkwoorden, maar vormt ze (uit andere woordsoorten) waar je bijstaat, waarbij het onderscheid toestand-proces-activiteit èn het soort object, 
goal of patiens, de vorm mede bepalen. Sprekers van een 'topic-comment taal' helpen aan nieuwe grammaticale inzichten lukte vooral via een puur lexicale en psycholinguistische benadering, waarbij je uitgaat van de betekenis en bruikbaarheid van woorden en uitdrukkingen. Daarover heb ik op verzoek van de Faculteit nog een boekje (in het Indonesisch) ${ }^{11}$ gepubliceerd, over contrastieve analyse, nucleaire en extranucleaire elementen, dat vermoedelijk nooit door iemand gelezen is. Met de studenten, òf schatrijk òf straatarm, die overigens best degelijk intellectueel werk konden leveren, ${ }^{12}$ heb ik goed contact kunnen leggen: die konden heel wat frustraties kwijt bij de veilige buitenstaander die ik was. Het heeft me een paar goede vrienden, een extra (pleeg)zoon en twee gratis kleinkinderen erbij opgeleverd. ${ }^{13}$ Enige tijd kostte het me, vernederlandst als ik was, de mores van een wij-samenleving te (her)ontdekken en vooral te waarderen. Later heb ik voor mijn werk als NT2-ontwikkelaar veel gehad aan de kennis van zowel andere denkwijzen en manieren van leren als aan de normen en waarden van een wij-cultuur.

Markant waren mijn eigen ervaringen met Indonesisch leren, tijdens een intensieve cursus in Amsterdam. Ik had als kind vloeiend Maleis (de lingua franca in een Archipel met van oorsprong 300 talen) gesproken en dat gaf mij ruim twintig jaar later een voorsprong (een perfecte uitspraak), die kennelijk geleid heeft tot de gedachte dat ik paranormaal begaafd was. Dus verhoogde de cursusleider het tempo en leerde ik in feite ... niks, zo bleek later in Jakarta, waar ik niemand verstond. Maar ik kon wel al heel wat nutteloze dingen zeggen! Erg gewaardeerd heb ik wel de kennis over de islam die ik op die stoomcursus opgedaan heb.

$U$ spreekt over een culture shock, toen $u$ in een Nederlands pleeggezin belandde. Heeft u meer van dat soort ervaringen gehad?

Ja, zeker! Toen ik, na 20 jaar terug in Indonesië, ontdekte hoezeer ik verhollandst was. En helemaal door de wijze waarop mij dat duidelijk werd. Een shocktherapie, mij geboden door een bevriend cultureel antropoloog, Koentjaraninggrat, aan wie ik om advies gevraagd had: ik begreep allerlei reacties niet goed en dat in Indonesië, toch mijn moederland! Zijn reactie: ' $U$ komt niet vertellen hoe het moet, maar vragen hoe het zit? $U$ bent welkom!' Door hem vervolgens op de thee genodigd werd mij gevraagd mijn ervaringen te vertellen. $\mathrm{Na}$ een poosje wat gefrustreerd voorbeelden spuien werd ik onderbroken met de woorden 'Als observator kunt $\mathrm{u}$ heel goed zijn, collega. Maar wetenschappelijk bent $u$ ver beneden sub-eerste 
jaars!' Daarop vertelde hij mijn 'verhaaltjes' opnieuw, stuk voor stuk, maar nu vanuit het perspectief van de Indonesiër. Eerst kwam er de herkenning: dat is waar ook, had ik eigenlijk nog kunnen weten! Daarna de schaamte: wat bevooroordeeld en stom! Dus zei ik na een poosje, dat ik het wel begrepen had, maar hij ging door, onverbiddelijk! En natuurlijk met een beleefde, vage glimlach. Het was bepaald niet de leukste, maar wel de beste les die ik ooit gehad heb en hij heeft me geleerd de rest van mijn leven het oordeel op te schorten en de waarneming te scherpen.

\section{Hoe verliep uw verdere carrière?}

Je oordeel opschorten en je waarneming scherpen bleken eigenschappen die ik goed kon gebruiken bij mijn rol als docent eerst Creatief Schrijven, later Intercultureel Onderwijs \& NT2, aan de toenmalige Nieuwe Leraren Opleiding VLVU, tegenwoordig Hogeschool Inholland in Amsterdam. Na mijn ervaringen met Indonesische studenten, die ik vaak wel erg volgzaam vond, dacht ik hier te maken te krijgen met vrije mensen, maar dat viel nogal tegen. Mijn colleges Creatief Schrijven maakten veel meer los bij de eerstejaarsstudenten dan ik voorzien had. Ze zaten grotendeels in een pantser van vooroordelen en angsten waar ze echt uit gepeuterd moesten worden. De meesten reageerden positief op de zittingen en leerden beter observeren, het oordeel uitstellen en technieken toepassen om op nieuwe ideeën te komen. Sommigen hechtten zelfs grote waarde aan deze lessen. Een enkeling sloeg door: 'Siel, ik ben verliefd op je! Wat doen we daaraan?'

U was 39 jaar docent taalverwerving aan de Hogeschool Inholland. Een aantal keren was u ook in Hongarije als gastdocent. U hebt onder andere in Debrecen college gegeven. Hoe was uw ervaring met de studenten, collega's, het land, de cultuur?

Amsterdam is een stad waarin (bij telling in 1984) 132 nationaliteiten voorkwamen. Tijdens stages eind zeventiger jaren kwamen studenten van ons voor klassen te staan, waarvan de helft hen niet verstond. Dus kwam er een roep om aanpassingen van het studieprogramma, waarvoor ik, met mijn ervaring in Jakarta, aangewezen werd. Die taak ben ik begonnen met observaties in speciale opvangklassen (de term internationale schakelklas bestond nog niet) om te kijken hoe men 'Nederlands als Vreemde Voertaal', zoals ik het toen nog noemde (later NT2,) leerde. Dat viel op het 
eerste gezicht best mee: er werd gemotiveerd en hard gewerkt, vaak onder leiding van een vrolijke en bezielende leerkracht. Toch bleek de 'drop out' uit het reguliere onderwijs ná de schakelklas behoorlijk hoog, zo'n $40 \%$ werd geschat. (Exact onderzoek was er nog niet.) En ze konden toch vaak al heel aardig babbelen! Nader onderzoek leverde mij op, dat het gegeven onderwijs meer leek op traditioneel vreemdetalenonderwijs (woordjes leren en grammatica) dan op onderwijs in een vreemde voertaal, zoals bijvoorbeeld Molukse collega' s allang wèl ontwikkeld hadden. Mijn ervaringen in Jakarta hadden me drie regels opgeleverd: 'betekenis gaat vóór vorm', 'geen grammatica als onderdeel van taalbeheersing' en 'woordjes stampen is een vluchtroute.' Dus ben ik, met collega's in het veld, die telkens onze ideeën testten, op zoek gegaan naar werkvormen en oefentypen die het, qua retentie en begrip van taal- en cultuuruitingen, wèl goed deden. Dat resulteerde uiteindelijk in de Audiolexicale Methode, waarbij je talen leert zonder memoriseren, later tot concrete leergang ${ }^{14}$ gemaakt i.s.m. collega's in Den Haag. Ik heb de methode zelf ook toegepast, als elementaire leergang in een intensieve cursus NT2 voor toekomstige studenten aan H.B.O. en Universiteit en later helemaal omgewerkt voor kinderen in de Nederlandse Antillen. Docenten lazen kennelijk vrijwel nooit de zg. Docentenhandleiding, zo ontdekte ik. De consequentie daarvan was dat er veel fouten gemaakt werden tegen de methodiek, zoals direct herhalen van zinnetjes i.p.v. eerst luisteren, toch woordjes stampen, taalfouten aanleren t.g.v. gedwongen snel praten en voortijdig met grammatica hobbyen. Om dat probleem te verhelpen heb ik in de loop der jaren letterlijk duizenden collega's in de halve wereld bijgeschoold, alweer via ervaringsleren. In dat kader ben ik, door een Hongaarse collega die in Nederland in de praktijk kennis had gemaakt met onze leergang, ook uitgenodigd naar Debrecen.

Daar reageerden collega's (Russisch, die Duits moesten gaan geven) en studenten aanvankelijk soms verbijsterd op onze ideeën, die ik overigens via concrete lessen in het Indonesisch liet ervaren. Je begon met muziek of Total Physical Response, je reageerde eerst alleen non-verbaal op vreemde taaluitingen, mocht fouten maken, mocht niet stampen, hoefde heus niet alles te onthouden, stelde praten en schrijven uit, mocht zingen relevanter vinden dan spreken, je deed veel dramatische werkvormen en werd beloond (i.p.v. getest) d.m.v. reageren op fouten: er waren er, die niet wisten wat ze overkwam. Het expliciet meetbaar maken van begrip, waar in het onderwijs haast geen aandacht voor was, werd vast onderdeel van je taak als docent: je testte het en had succes. Mijn Hon- 
gaarse collega's stonden best open voor bruikbare ideeën, waren over het algemeen buitengewoon aardig en gastvrij en gaven me zelfs een gratis 'cursus' Tokajer wijnen proeven.

\section{Heeft u nog contact met Hongarije?}

Neen, geen direct contact meer, alleen via Facebook en Messenger. En dan nog met een enkele vriendin of collega. Als je eenmaal mantelzorger bent en daardoor gedwongen in de buurt van of direct oproepbaar door je hulpbehoevende partner te blijven, kun je in principe geen verre reizen meer maken.

\section{Hoe ziet u de Hongaarse cultuur in Nederland?}

De contacten, die ik heb, zijn schaars geworden. Ik heb bijvoorbeeld nog één leerling uit Hongarije voor NT2. Ik krijg dus niet veel meer mee van de Hongaarse cultuur hier. Het enkele contact, dat ik nog spreek, zegt zich te schamen voor de rol van Orbán in Hongarije en Europa. Hongarije ligt er met Polen in de publieke opinie, beïnvloed als die is door de media, een beetje uit. Het is jammer dat de bewoners van een land beoordeeld worden naar hun politieke leiders, maar er is weinig tegen te doen. Ik zie zelf, afgezien van de zigeunermuziek en geweldige dansvoorstellingen, ook geen rol van belang voor de Nederlandse samenleving. Hongaren en $\mathrm{Ne}-$ derlanders lijken eigenlijk best op elkaar, vind ik, althans qua vriendelijkheid en behulpzaamheid èn het gevoel niet altijd even goed begrepen te worden. Het grootste verschil zie ik in de Hollandse botheid, eigengereidheid en de manie altijd 'gidsland' te willen zijn, hoe ver ze soms ook achterliggen.

Heeft $u$ wel eens voor ernstige dilemma's gestaan in uw carrière? Zo ja, welke?

In het voortgezet onderwijs lag ik regelmatig in de clinch met collega's en schoolleiding: het ging dan om belangen van leerlingen, gewoonlijk niet de populairste, met specifieke problemen. Pogingen om mij voor het dilemma leerlingenbelang versus schoolbelang (veelal angst voor ouders) te plaatsen trapte ik niet in. Werd het me te gek dan dreigde ik met 'naar de pers' te gaan en dat bleek afdoende. Maar je wordt in ons vak vaak genoeg voor echte gewetensproblemen geplaatst, zoals bij leerlingen met 
dreigende psychische of psychosomatische problemen. Je had je dan te schikken in beslissingen van schoolarts of psychiater, die je slapeloze nachten konden bezorgen. Zocht je zo'n 'geval' dan op, bijvoorbeeld in een psychiatrische inrichting waar met LSD werd geëxperimenteerd en je trof een soort zombie aan, dan werd je wezenlijk geraakt door een tragiek, waar je niets meer aan kon doen. Het is een weinig belichte kant van het vak en verdient zeker plaats in een gedegen leraarsopleiding voor de $21^{e}$ eeuw, als die er ooit komt. Wat een ernstig dilemma is geweest: de vraag hoelang ik me moest blijven inzetten voor de verbetering van het NT2-onderwijs en de inburgeringslessen in Nederland. Het is namelijk verbijsterend hoe hardleers het onderwijs kan zijn: bestudeer je de geschiedenis van het (taal)onderwijs, dan blijkt dat er veel waardevolle ideeën teloor zijn gegaan en dat vrijwel elke 'vernieuwing' òf een bezuiniging òf opgepoetst antiek is. Zo berust het in de zeventiger jaren als nieuwe werkwijze 'ontdekte' Total Physical Response op inzichten, die in de leerboeken in Nederlands-Indië al standaard waren rond de ... dertiger jaren! De recente 'ontdekking' in Nederland dat betekenis vóór vorm gaat, hebben wijzelf zo'n veertig jaar geleden toegepast in Spreken is zilver ..., overigens een leergang waar geen enkele nieuwe werkvorm in voorkomt, maar die bij verschijning direct te boek stond als nieuw en zelfs revolutionair. En, wat me ronduit verdriet: mij worden soms nieuwe 'methoden' (bedoeld is leergangen) ter beoordeling toegestuurd waar precies dezelfde fouten in gemaakt worden als 50 jaar geleden, waarbij cursisten grammatica-, discourse- en beleefdheidsfouten leren. (Ik beoordeel ze dan ook niet.) En dan ... Digilemma, een nieuw type leerwoordenboek op basis van psycholinguistische richtlijnen, waar ik met 3 collega's (waaronder een oud-medewerker aan het Woordenboek der Nederlandse Taal) jaren aan heb gewerkt en dat uiteindelijk niet geaccepteerd werd, ondanks propagering ervan door een bekende (TPRS-)collega: bij een enquête onder VO-docenten bleek, dat slechts een kleine minderheid er iets in zag.

\section{Heeft $u$ een soort eindoordeel over het VTO, en ja, hoe luidt dit dan?}

De verbazing dat wetenschappelijk gezien aantoonbaar goede ontwikkelingen telkens weer ingehaald kunnen worden door ideeën die berusten op traditie (en dus bijgeloof) ben ik nooit echt te boven gekomen. Ik ben dan ook begonnen aan een boek daarover: Ongeneeslijk, maar niet ziek. (Het ziet ernaar uit, dat dit nooit zal verschijnen, want ik kan er geen tijd meer voor maken.) 83 jaar oud en een tikkeltje wijzer geworden moet ik me ge- 
woon neerleggen bij de feiten. En die zijn dat het onderwijs, van oorsprong bedoeld om een beschaving te bestendigen d.m.v. overdracht van kennis die niet teloor mag gaan, zowel conserverend als cyclisch is. Conserverend (en niet vooruitstrevend), want het moet helpen kennis en vaardigheden te behouden voor nieuwe generaties. Cyclisch (en niet lineair), want het moet zichzelf telkens weer uitvinden: elke docent moet zijn eigen vorm vinden en daarbij in zekere zin het wiel opnieuw uitvinden. De Hongaar in mij zegt dan: het idee van een lineaire ontwikkeling met aantoonbare vooruitgang, waarin ik zo lang geloofd heb, blijkt onmenselijk, net zoals het naïeve bijgeloof dat de mensheid zou leren van zijn geschiedenis. Jammer, jammer, jammer. En de Hollander in mij zegt: Wat overeind blijft is de zekerheid dat steeds nieuwe generaties docenten idealistisch, betrokken en met een bewonderenswaardige inzet het onderwijs, en vooral hun leerlingen, blijven redden. Met vallen en opstaan natuurlijk! En wat dan nog?

\section{Waarop baseert u dat 'Hollands' optimisme?}

Bij een cursus Creatief Schrijven, ontwikkeld in 1975, had ik ook lessen 'Tegen honds gedrag' opgenomen: ga in de klas nooit intuïtief af op je eerste indrukken, want dat is vluchtdier-gedrag, weliswaar heel natuurlijk, maar in het onderwijs keert dat zich tegen je. Die zittingen behelsden een poging om natuurlijke, spontane reacties op alles wat afwijkt (die steevast uitmonden in vooroordelen, discriminatie en stereotype stappen als afstraffen), bewust te maken en via uitgesteld oordeel te leren beheersen. Geen kleinigheid, want je probeert in feite een verandering in het vrijwel volwassen brein te bewerkstelligen: van amygdala, ons angstcentrum dat leidt tot intuïtieve reacties als schrik, vooroordeel en discriminatie, naar frontale cortex, dat juist staat voor overweging, planning en uitgestelde reacties. Maar hoe ingrijpend ook, het werd geaccepteerd en het werkte! De meeste studenten begrepen waar het om ging, deden goed mee met de training en leerden er wat van. De methode, die ik gebruikte om deze mentaliteitsverandering (zo heette dat toen nog) te bereiken, beschouwde ik als een persoonlijke aanpak, niet overdraagbaar aan anderen. Ik heb er dan ook geen nascholing over gegeven. Dus heb ik eigenlijk met lede ogen allerlei vruchteloze pogingen, heel vaak neerkomend op preken voor eigen parochie, moeten aanzien; ik heb er zelfs nog aan deelgenomen, met 'interessante lezingen'. In feite was ik zover te geloven, dat tegen kortzichtigheid en discriminatie niets is opgewassen. 
Maar de laatste tijd komen zg. 'mindset-trainingen' via mindfulness, op gang. Daar heb ik me, gezien mijn prioriteiten (NT2 en VTO), aanvankelijk niet genoeg in kunnen verdiepen. Momenteel begint het werk van neurowetenschapper Emile Bruneau ${ }^{15}$ echter bekend te worden. Hij heeft serieus onderzocht, wat je tegen vooroordelen en discriminatie kunt beginnen en kwam uit op drie dingen: ons vermogen kritisch te denken, de plasticiteit van ons brein en strategieën als mindfulness en onderwijs. Eigenlijk komt alles neer op 'Luister nou!', maar de omwegen en trainingen om dat te bereiken blijken, hoe veeleisend ook, rendabel: het werkt!

$\mathrm{Na}$ een levenslang vechten tegen vooroordelen in ons werk, waarbij ik eerlijk gezegd geregeld de moed verloor, zie ik in deze ontwikkeling iets, dat echt hoop geeft. Het zou mooi zijn als zulke inzichten en technieken opgenomen werden in een (voorlopig imaginaire) Lerarenopleiding voor de $21^{e}$ eeuw. Vandaar dus.

En die Hongaarse namen van $u$, in hoeverre zijn die waargemaakt?

Een krachtfiguur heb ik zeker de nodige keren moeten zijn, hoewel dat wel begrensd werd door het feit, dat ik mensen niet graag persoonlijk aantast, verneder of nodeloos kwets. In dat opzicht ben ik duidelijk geprogrammeerd door mijn keurige moeder. In termen van succes in mijn onderwijscarrière heeft mijn doordouwen alleen iets betekend voor personen, dus mijn studenten en collega's, die lieten zien, wat ze in de praktijk aankonden met mijn ideeën: vaak voorbeeldige onderwijsprestaties, die veel waardering oogsten èn die ze geregeld zo vriendelijk waren met mij te delen. Nog steeds krijg ik bewijzen van geleverde kwaliteit, en dat is best kicken. Voor het onderwijs als zodanig heeft mijn doordouwen echter weinig betekend. Diep in mijn hart had ik gedroomd met een degelijke elementaire cursus iets wezenlijks bij te dragen aan goed NT2en Intercultureel onderwijs: maar voor het daarbij behorend gevecht tegen de bierkaai blijk ik verkeerd opgevoed! In feite voel ik me dus een buitenstaander met achterhaalde idealen, kind uit een wij-cultuur verdwaald in het ikke-ikke-en-de-rest-kan-stikken van het huidige marktdenken. Maar als ik mag kiezen tussen enerzijds bejaard en rancuneus en anderzijds oud en wijs, kies ik voor het laatste. 
Noten

1 In 1676 bevrijdde Michiel de Ruyter 26 Hongaarse predikanten, galeislaven in Spaanse gevangenschap. Deze daad is niet vergeten: nog steeds eert Hongarije deze 'De Ruyter Mihály'. Voor hem is een bescheiden standbeeld opgericht in Debrecen. Daar werden tijdens de Russische bezetting elke nacht bloemen bij gelegd, als soort verzetsdaad, zo is mij in 1992 door omwonenden verteld.

2 Waarbij het feit dat het Nederlands veel werkt met metaforen, die je dus niet letterlijk moet nemen, het niet makkelijker maakt.

3 'Blubbertjespap', een soort smakeloze stijfsel zonder enige voedingswaarde, en slakkensoep, waar soms een enkel rubberachtig slakkenlijkje in ronddreef, waren onderdelen van het menu.

4 In dat 'bevrijdingskamp' probeerden sommige jongens, die hun na vier jaar teruggevonden vader vonden tegenvallen, die te ruilen met een beter exemplaar. Een enkeling wilde zelfs wel 'bijbetalen'

5 Een typering die indertijd in ambtelijke stukken gebruikt werd: 'een Indo (natuurlijk achterbaks)'

6 In 1947 had ene Juffrouw De Die (gezegend zij haar naam) in Baarn mij in een half jaar door drie leerjaren lagere school geholpen, 'gewoon telkens een half uurtje' na de reguliere lessen: ik kon voortaan meedoen met alle vereiste vaardigheden in de vierde klas. Ruim dertig jaar later, toen ik me ging verdiepen in transculturele communicatie en intercultureel onderwijs realiseerde ik me, dat dit het hoofdprobleem van het tweede taal-onderwijs is: wel veel woordjes en taalvaardigheden, maar niet de culturele ballast erachter of training hoe ermee om te gaan.

7 Van Frederic Vester, in 1976 notabene 'boek van de maand'.

8 Vooral sinds zijn optreden voor BON (Beter Onderwijs Nederland) in 2008 met Over onderwijs, brein, en bovenwijs.

9 Crone E.A. 2008. Het puberende brein. Amsterdam: Bert Bakker.

10 Daarbij heb ik veel gehad aan Clara (die ik dit jaar 65 jaar ken) niet alleen als vrouw en maatje, maar ook als collega conversatielessen in Jakarta, waar zij eerst een soort TPRS (met de verhalen van Jip en Janneke als uitgangspunt) ontwikkelde, daarna mij hielp om muziek als werkvorm in het VTO te integreren. En als eyeopener: Clara's latere studie orthopedagogiek bracht nieuwe boeken en ideeën in huis, waaraan ik voor de ontwikkeling van het NT2-ondewijs minstens zoveel gehad heb als aan de colleges creatief schrijven die ik had ontwikkeld voor de eerstejaars.

11 Pengantar Tata Bahasa Kontrastif Indonesia - Belanda (Inleiding in de contrastieve analyse Indonesisch -Nederlands), Fakultas Sastra Universitas Indonesia, Jakarta,1980

12 Wat men in Leiden, waarmee we samenwerkten, weigerde te geloven. Van een goede scriptie van onze studenten zeiden ze daar: zal wel door Siel geschreven zijn.

13 Kinderen van een student dus, die Clara en mij als oma en opa benaderden, vanaf Schiphol belden en een paar weken lekker bij ons in Voorburg kwamen logeren. Normaal voor een wij-samenleving.

14 Die is onder de naam Spreken is zilver ... (voor NT2 en inburgering), later aangepast en vermeerderd tot ffNLleren (voor NT2 en Nederlands als Vreemde Taal) bekend 
geworden. En Natuurlijk Nederlands leren! Was de Audiolexicale leergang voor kinderen op de Nederlandse Antillen

15 Zie o.a. https://www.caringbridge.org/visit/emilebruneau 